\title{
Challenges for adherence to bacterial resistance actions in large hospitals
}

\author{
Desafios para adesão às ações de contenção da resistência bacteriana em hospitais de grande porte \\ Desafíos para la adherencia a las acciones de resistencia bacteriana en grandes hospitales
}

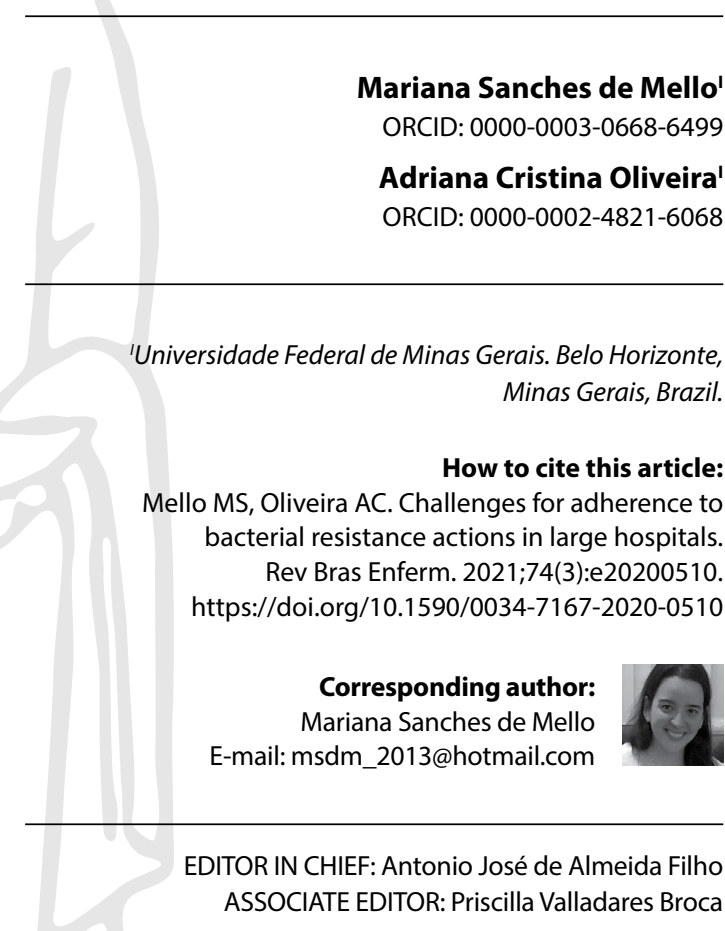

Submission: $07-13-2020$

Approval: $02-23-2021$

\begin{abstract}
Objectives: to identify the challenges to actions to contain bacterial resistance. Methods: cross-sectional study, carried out in 30 large-sized hospitals in Minas Gerais, from 2018 to 2019. The professionals were interviewed, and the environment and actions to prevent bacterial resistance were observed. Results: regarding the knowledge of health care professionals about the measures of bacterial resistance prevention, $78.3 \%$ did not correctly describe the five moments of hand hygiene, and $76.6 \%$ did not correctly describe the measures to control bacterial resistance. The simple hygiene of hands, followed by alcohol rubbing was predominant (48.3\%) among workers, and soap dispensers were next to alcohol dispensers in $58.3 \%$ of the nursing stations in care units. Conclusions: the insufficient knowledge from the professionals, which is a failure related to the physical structure and to personal protection equipment, are factors that difficult the adherence to measures to contain bacterial resistance in hospitals. Descriptors: Cross Infection; Drug Resistance, Bacterial; Patient Safety; Hand Hygiene; Precaution.
\end{abstract}

\section{RESUMO}

Objetivos: identificar as dificuldades para adesão às ações de contenção da resistência bacteriana. Métodos: estudo transversal, realizado em 30 hospitais de grande porte de Minas Gerais, de 2018 a 2019. Entrevistaram-se os profissionais; observaram-se o ambiente e as ações de prevenção da resistência bacteriana. Resultados: sobre o conhecimento dos profissionais assistenciais acerca das medidas de prevenção da resistência bacteriana, $78,3 \%$ não descreveram corretamente os cinco momentos para higienização das mãos; e 76,6\%, as medidas de controle da resistência bacteriana. Identificou-se que a higienização simples das mãos seguida por fricção alcoólica foi predominante $(48,3 \%)$ entre os profissionais e que dispensadores de sabonete eálcool estavam lado a lado em $58,3 \%$ dos postos de enfermagem das unidades assistenciais. Conclusões: o conhecimento insuficiente dos profissionais, falhas relacionadas à estrutura física e aos equipamentos de proteção individuais são fatores dificultadores para a adesão às medidas de contenção da resistência bacteriana nos hospitais. Descritores: Infecção Hospitalar; Farmacorresistência Bacteriana; Segurança do Paciente; Higiene das Mãos; Precaução.

\section{RESUMEN}

Objetivos: identificar dificultades para adhesión a acciones de contención de resistencia bacteriana. Métodos: estudio transversal, realizado en 30 grandes hospitales de Minas Gerais, de 2018 a 2019. Entrevistaron profesionales; observaron ambiente y acciones de prevención de resistencia bacteriana. Resultados: el conocimiento de los profesionales asistenciales acerca de medidas de prevención de resistencia bacteriana, $78,3 \%$ no describieron correctamente los cinco momentos para higienización de las manos; $y 76,6 \%$, las medidas de control de resistencia bacteriana. Identificó que la higienización simple de las manos seguida por fricción alcohólica fue predominante $(48,3 \%$ ) entre los profesionales y que dispensadores de jabonete y alcohol estaban lado a lado en $58,3 \%$ de los puestos de enfermería de las unidades asistenciales. Conclusiones: el conocimiento insuficiente de los profesionales, fallas relacionadas a la estructura física y a los equipos de protección individuales son factores dificultadores para la adhesión a las medidas de contención de resistencia bacteriana en hospitales.

Descriptores: Infección Hospitalaria; Farmacorresistencia Bacteriana; Seguridad del Paciente; Higiene de las Manos; Precaución. 


\section{INTRODUCTION}

Health care-associated infections ( $\mathrm{HAl}$ ) are among the most recognized adverse effects in the world, since this type of health problem is not only avoidable, but also frequent, threatening the safety of patients and representing a high unnecessary cost to the health system ${ }^{(1-2)}$. Respiratory, urinary tract, bloodstream, and surgical infections are the most frequently notified HAls in the health services ${ }^{(2-3)}$.

In the hospital environment, most bacteria that cause HAls are resistant to at least one of the antimicrobial agents used for the treatment of patients. In Europe, one in every three infections in hospitals involves antibiotic-resistant bacteria as causing agents ${ }^{(2,4)}$.

The HAls associated to resistant bacteria take place throughout the units of assistance within the hospitals. However, they have been recorded more frequently in patients of Intensive Care Units (ICUs). This finding is largely due to the profile of ICU patients, who have serious base illnesses ${ }^{(2-3,5)}$ and undergo invasive procedures more often, in addition to surgeries and to the use of antimicrobial agents ${ }^{(6)}$.

The excessive and unnecessary or mistaken exposure to antimicrobial agents leads bacteria to become resistant, which can happen due to changes in their genetic material, the induction of chromosome mutations, or the acquisition of resistant genetic material, which can be transferred between different genders or species of bacteria ${ }^{(2,7)}$.

However, in addition to genetic mechanisms of bacterial resistance, it must be considered that resistant bacteria can also be disseminated by the hands of health professionals who get in touch with colonized or infected patients or with the environment or surfaces near these patients ${ }^{(2,8-9)}$.

The practice of hand hygiene ${ }^{(10)}$, associated with standard plus contact precautions ${ }^{(11)}$, limits the transmission of resistant microorganisms. This, in turn, reduces the number of preventable infections, reducing morbimortality in health services ${ }^{(2)}$.

In this setting, in which measures that are relatively simple to implement, can contribute to prevent the dissemination and emergence of resistant microorganisms. There are three essential guidelines strongly recommended by national and international protocols: hand hygiene, the rational use of antimicrobial agents, and the adherence to standard plus contact precautions by health professionals ${ }^{(2-3,8)}$.

Recognizing the worldwide impact of bacterial resistance in public health, the World Health Organization (WHO) has established many programs that seek to contain this health problem, aiming to make rational use of antimicrobial agents in human and animal health, to reduce infections through preventive measures, raise awareness about bacterial resistance in the world, and encourage researches that seek to increase the investment in new drugs and health solutions ${ }^{(2,12)}$.

From this perspective, health workers are key-players to help reaching these goals, since the potential paths towards controlling the dissemination of bacterial resistance go through the knowledge and behavior of these professionals, who must adopt the recommendations ${ }^{(2,13)}$.

\section{OBJECTIVES}

To identify the difficulties to adhere to actions to contain bacterial resistance in large hospitals in Minas Gerais.

\section{METHODS}

\section{Ethical aspects}

This study is part of the project "Panorama of Global Challenges from the World Health Organization for the Safety of Patients in Large-Sized Hospitals in Minas Gerais", submitted and approved by the Research Ethics Committee of the Universidade Federal de Minas Gerais (COEP/UFMG).

\section{Design, period, and place of study}

This is a cross-sectional observational study in which factor and effect were analyzed in a single historical moment. The study was carried out in Minas Gerais, from February 2018 to April 2019. The instrument used to guide the methodology of this research was the Strengthening the Reporting of Observational Studies in Epidemiology (STROBE).

\section{Population; criteria of inclusion and exclusion}

To select the establishments, large general hospitals from Minas Gerais were listed. According to the National Register of Health Establishments (CNES), 542 hospitals were identified as general hospitals; 32 of them were classified as large. The term "general hospital" is here understood as referring to hospitals that attend to many areas, while any hospital which has from 150 to 299 beds was considered to be large, according to Decree No. $2.224 / \mathrm{GM}^{(2,14)}$. For the establishment to be included in the study, the following criteria were defined: large-sized general hospitals located in Minas Gerais, in one of the health macro-regions defined by the state. Specialized hospitals, as well as those with less than 150 beds, were excluded.

The eligible hospitals in the capital of the state, Belo Horizonte, were invited to participate by the Municipal Health Secretariat; the others were invited by the State Health Secretariat. Both secretariats were partners in the conduction of the study, due to their interest in finding out about the theme. The representative of all hospitals invited received clarifications about the objectives of the study and was notified that the visit was not an inspection, but targeted at designing a panorama about how hospitals have been conducting their actions, promotion, and practice of patient safety policies ${ }^{(2)}$.

The agreement of the institution to the visit was understood as acceptance to participate in the study. The scheduling was done according to the availability of the institution, and the acceptance was voluntary and anonymous, with no financial benefit or coercion. The interviewees were aware that they could abandon participation at any point in time, information which was reinforced during the visit and detailed in the Free and Informed Consent Form ${ }^{(2)}$. 
30 large hospitals from Minas Gerais participated in the study. After the legal representatives of each institution gave their consent, in-person interviews were carried out with the coordinators of the Hospitalization Units (HUs) and of the ICUs. Simultaneously, the following elements were observed: the adoption of bacterial resistance prevention and control measures by the multiprofessional teams in the care units of the hospitals; and the physical structure of the hospitals, assessed using a situational diagnosis.

The data collection team was made up by researchers from the nursing school of the Universidade Federal de Minas Gerais, in addition to sanitary surveillance professionals from the Municipal Health Secretariat (SMS), when the hospital was in the capital, or sanitary surveillance professionals from the State Health Secretariat (SES), when the hospital was elsewhere in the State ${ }^{(2)}$. In each participating hospital, 1 professional was interviewed, adding up to 30 in each assistance unit, a total of 60 professionals.

\section{Study protocol}

The study used structured questionnaires, based on recommendations proposed by the Centers for Disease Control and Prevention $(C D C)^{(8)}$. They were translated into Portuguese and previously tested in a pilot study. This aimed at validating the instruments, and the data obtained is not presented in this study. Data was collected following two simultaneous stages, as described in Chart 1.

Chart 1 - Stages of the conduction of the study

\begin{tabular}{|c|c|c|c|c|}
\hline Stage & $\begin{array}{l}\text { Data collection } \\
\text { instrument }\end{array}$ & Method & Participants & Goals \\
\hline $1^{\mathrm{a}}$ & $\begin{array}{l}\text { Structured } \\
\text { questionnaires }\end{array}$ & $\begin{array}{l}\text { Face-to-face } \\
\text { interview }\end{array}$ & $\begin{array}{l}\text { Coordinators } \\
\text { of the } \\
\text { Hospitalization } \\
\text { Unit and of the } \\
\text { Intensive Care } \\
\text { Unit }\end{array}$ & $\begin{array}{l}\text { To identify the knowledge } \\
\text { about the actions implanted } \\
\text { and executed to prevent and } \\
\text { control bacterial resistance, } \\
\text { and the standard plus } \\
\text { contact precautions. }\end{array}$ \\
\hline $2^{a}$ & $\begin{array}{l}\text { Structured } \\
\text { questionnaires }\end{array}$ & Observation & $\begin{array}{l}\text { Workers in } \\
\text { the physical } \\
\text { area of the } \\
\text { Hospitalization } \\
\text { Unit and } \\
\text { Intensive Care } \\
\text { Unit }\end{array}$ & $\begin{array}{l}\text { To evaluate the conditions for } \\
\text { the adoption of measures to } \\
\text { prevent and control bacterial } \\
\text { resistance, hand hygiene } \\
\text { in clinical practice, and } \\
\text { assess the availability of the } \\
\text { infrastructure and of supplies } \\
\text { to guarantee the actions } \\
\text { of prevention through } \\
\text { situational diagnoses. }\end{array}$ \\
\hline
\end{tabular}

To evaluate moments of hand hygiene, more than one professional was monitored and observed during the practice of the five moments of hand hygiene. The choice of these professionals took place according to the activities that they were performing at the moment of data collection.

\section{Data analysis}

The data collected was analyzed using the software Statistical Package for the Social Sciences (SPSS), version 22.0, using descriptive statistics to characterize the population studied, including the calculation of absolute and relative frequencies, central tendency and dispersion measures for quantitative variables ${ }^{(2)}$.

\section{RESULTS}

When the coordinators (all of them nurses) of the care units were questioned about the importance of bacterial resistance in their sectors, $100 \%(n=60)$ informed that it is a very relevant issue; $50 \%(n=15)$ in the HUs and $42.2 \%(n=13)$ in the ICUs said that they knew the practices recommended by the WHO to control bacterial resistance ${ }^{(2)}$.

Table 1 presents the answers of the nursing coordinators of the sectors, indicating their knowledge about the following topics: measures of bacterial resistance and control; standard precaution measures; multiresistant microorganisms; the conduct for patients in contact precautions; the five moments of hand hygiene; and the principle of the Collegiate Directorate Resolution 42/2010 by ANVISA (the National Sanitary Surveillance Agency) ${ }^{(2,15)}$.

Among the measures that difficult controlling bacterial resistance in the clinical practice, $60 \%(n=36)$ professionals from both units demonstrated low adherence to hand hygiene, followed by an insufficient adherence to standard plus contact precautions $(46.7 \% . n=14)$ in the ICUs and $(43.3 \% ; n=13)$ in the $\mathrm{HUs}^{(2)}$.

The lack of criteria for the prescription of antibiotics (15\%; $n=$ 9), the difficulties related to supplies and equipment $(13.3 \% ; n=$ $8)$, the issues related to personnel sizing and turnover $(13.13 \% ; n$ $=8)$, the cleanliness of the environment $(6.6 \%$; $n=4)$, the flaws in the delivery of results by laboratories ( $5 \% ; n=3)$, and the indication for unnecessary invasive procedures $(3.3 \% ; n=2)$ were also pointed out as elements that make bacterial resistance more difficult in the hospitals ${ }^{(2)}$.

When questioned about the most common type of hand hygiene among professionals in both units, simple hand hygiene was mentioned in 55\% ( $n=33$ ) of units. Regarding the type of sanitization adopted by workers right before handling patients, in cases where their hands were visibly dirty or uncontaminated, $63.3 \%$ (n = 19) from the ICUs and $53.3 \%(n=15)$ from the HUs answered that they rub their hands using alcohol $70 \%{ }^{(2)}$.

Among the factors that difficult adherence to hand hygiene in clinical practice, which the workers selected from multiple-choice questionnaires, $51.7 \%(n=31)$ chose the hurry, caused by the lack of personnel and work overload; $46.7 \%$ ( $n=$ 28) mentioned individual cultural aspects of the workers, such as biosafety culture and not believing in the efficacy of this procedure; $8.3 \%(n=5)$, the malfunctioning of the dispensers; $6.6 \%$ $(n=4)$, the lack of supplies and materials for hand hygiene and a physical structure that required moving to reach the alcohol for hand rubbing; and $1.6 \%(n=1)$ mentioned the low quality of the products, that risked causing allergic reactions ${ }^{(2)}$.

Although nurses reported that simple hand hygiene was the most common method, it was found, through a situational diagnosis, that the predominant type of hygiene was simple 
Table 1 - Knowledge of the nursing coordinators of the Hospitalization Units and Intensive Care Units $(N=60)$ of the large hospitals from the state of Minas Gerais $(n=30)$ who participated in the study, Belo Horizonte, Minas Gerais, Brazil, 2019

\begin{tabular}{|c|c|c|}
\hline Variable & $\begin{array}{c}\text { Intensive } \\
\text { Care Unit } \\
(\mathbf{n}=30) \\
n(\%)\end{array}$ & $\begin{array}{c}\text { Hospitalization } \\
\text { Unit } \\
(\mathbf{n}=\mathbf{3 0}) \\
\mathbf{n}(\%)\end{array}$ \\
\hline \multicolumn{3}{|c|}{ Identification of measures to control bacterial resistance } \\
\hline Incomplete & $17(56.7)$ & $16(53.3)$ \\
\hline Complete & $08(26.7)$ & $06(20.0)$ \\
\hline Does not know & 05 (16.7) & $08(26.7)$ \\
\hline \multicolumn{3}{|c|}{ Identification of standard precautions } \\
\hline Incomplete & $24(80.0)$ & $24(80.0)$ \\
\hline Complete & $02(6.7)$ & $04(13.3)$ \\
\hline Does not know & $04(13.3)$ & $02(6.7)$ \\
\hline \multicolumn{3}{|c|}{ Definition of multiresistant microorganisms } \\
\hline Incomplete & $13(43.3)$ & $13(43.3)$ \\
\hline Complete & $12(40.0)$ & $13(43.3)$ \\
\hline Does not know & 05 (16.7) & $04(13.3)$ \\
\hline \multicolumn{3}{|c|}{ Identification of contact precautions } \\
\hline Complete & $16(53.3)$ & $12(40.0)$ \\
\hline Incomplete & $14(46.7)$ & $15(50.0)$ \\
\hline Does not know & $00(0.0)$ & $03(10.0)$ \\
\hline \multicolumn{3}{|c|}{ Identification of the five moments of hand hygiene } \\
\hline Incomplete & $14(46.7)$ & $20(66.7)$ \\
\hline Complete & $11(36.7)$ & $02(6.7)$ \\
\hline Does not know & $05(16.7)$ & $08(26.7)$ \\
\hline \multirow{2}{*}{\multicolumn{3}{|c|}{$\begin{array}{l}\text { Identification of the principle of the Resolution of the Collegiate } \\
\text { Directorate No. 42, from the National Sanitary Surveillance Agency } \\
\text { (ANVISA) }\end{array}$}} \\
\hline & & \\
\hline No & $26(86.7)$ & $25(83.3)$ \\
\hline Yes & $04(13.3)$ & 05 (16.7) \\
\hline
\end{tabular}

Table 2 - Hand hygiene, according to its five moments, as observed in the assistance units $(\mathrm{N}=60)$ of large hospitals from Minas Gerais $(n=30)$ that participated in the study, Belo Horizonte, Minas Gerais, Brazil, 2019

\begin{tabular}{|c|c|c|}
\hline Variable & $\begin{array}{c}\text { Intensive } \\
\text { Care Unit } \\
\text { (n= 30) } \\
n(\%)\end{array}$ & $\begin{array}{c}\text { Hospitalization } \\
\text { Unit } \\
(\mathbf{n}=\mathbf{3 0}) \\
\mathbf{n}(\%)\end{array}$ \\
\hline \multicolumn{3}{|l|}{ Before aseptic procedures } \\
\hline Simple hygiene followed by rubbing alcohol & $13(43.3)$ & $11(37.9)$ \\
\hline Simple hygiene & $12(40.0)$ & $12(41.4)$ \\
\hline Rubbing alcohol & $02(6.7)$ & $01(3.4)$ \\
\hline Hand hygiene using an antiseptic & $02(6.7)$ & $00(0.0)$ \\
\hline No hand hygiene & $01(3.3)$ & $06(17.2)$ \\
\hline \multicolumn{3}{|l|}{ Before contact with the patient* } \\
\hline Simple hygiene followed by rubbing alcohol & $10(33.3)$ & $06(20.7)$ \\
\hline Simple hygiene & $09(30.0)$ & $07(24.1)$ \\
\hline No hand hygiene & 05 (16.7) & $07(24.1)$ \\
\hline Hand rubbing with alcohol & 05 (16.7) & $09(31.0)$ \\
\hline Hand hygiene using an antiseptic & $01(3.3)$ & $00(0.0)$ \\
\hline \multicolumn{3}{|l|}{ After contact with the patient* } \\
\hline Simple hygiene followed by rubbing alcohol & $14(46.7)$ & $10(34.5)$ \\
\hline Simple hygiene & $13(43.3)$ & $12(41.4)$ \\
\hline Hand rubbing with alcohol & $03(10.0)$ & 05 (17.2) \\
\hline No hand hygiene & $0(0.0)$ & $02(6.9)$ \\
\hline \multicolumn{3}{|l|}{ After the exposure to body fluid* } \\
\hline Simple hygiene followed by rubbing alcohol & $15(50.0)$ & $14(48.3)$ \\
\hline Simple hygiene & $13(43.3)$ & $12(41.4)$ \\
\hline No hand hygiene & $01(3.3)$ & $01(3.4)$ \\
\hline Hand hygiene using an antiseptic & $01(3.3)$ & $01(3.4)$ \\
\hline Hand rubbing with alcohol & $00(0.0)$ & $01(3.4)$ \\
\hline \multicolumn{3}{|l|}{ After contact with surfaces close to the patient* } \\
\hline Simple hygiene followed by rubbing alcohol & $09(30.0)$ & $07(24.1)$ \\
\hline Hand rubbing with alcohol & $08(26.7)$ & $11(37.9)$ \\
\hline Simple hygiene & $08(26.7)$ & 05 (17.2) \\
\hline No hand hygiene & $05(16.7)$ & $06(20.7)$ \\
\hline
\end{tabular}

hand hygiene followed by rubbing alcohol, as observed in specific situations in both sectors and described in Table $2^{(2)}$.

Through the situational diagnosis in the health care units, it was possible to see aspects of the infrastructure and supplies that favored the adherence to hand hygiene measures, and standard and isolation precautions, as presented in Table $3^{(2)}$.

Most (93.3\%; $n=56$ ) sinks had refillable soap dispensers made of easy-to-clean material (100\%; $\mathrm{n}=$ $60)$. From these, $85 \%(n=51)$ were already working at the moment of the visit $^{(2)}$. Regarding alcohol dispensers, all were easy to clean and refillable.

Still with regard to supplies for hand hygiene, it was found that, in $98.3 \%(n=59)$ of health care units, paper towel dispensers were also at the sinks, were easy to clean and did not show signs of oxidation. Furthermore, the paper towels were adequately stored within the dispensers (98.3\%; $\mathrm{n}=59$ ) and had good drying capabilities, enabling individual use, sheet by sheet $(96.7 \% ; n=58)$, not leaving any particles $(91.7 \% ; n=55)^{(2)}$.

About the personal protection equipment made available by the institution, in $65 \%$ ( $n=39$ ) of units, health workers used powdered gloves; in $20 \%(n=12)$, gloves with no powder; and in 15\% ( $n=9)$, both $^{(2)}$. The aprons used to care for the patient in contact precaution were mostly $(56.6 \% ; n=35)$ made of fabric in both units; were disposable in $35.9 \%(n=21)$ of them; and in $7 ; 5 \%(n=5)$, there both fabric and disposable aprons.

Considering the physical distribution of the beds, in $90 \%$ of sectors $(n=54)$, the distance between the was at least 1 meter. This result corresponded to $93.3 \%(n=28)$ of the ICUs and $86.7 \%(n=26)$ of the HUs. It was found that, in $48.3 \%(n=29)$ of the assistance units, there were physical barriers between beds, most of these $(90 \% ; n=27)$ being found in the ICUs ${ }^{(2)}$. The main physical barriers found in the ICUs were: walls (51.9\%; $n=14)$, curtains $(25.9 \% ; n=7)$, and individualized boxes $(22.2 \% ; n=6)$. 
Table 3 - Infrastructure of the assistance units $(N=60)$ of large-sized hospitals from Minas Gerais ( $n=$ 30) that participated in the study, Belo Horizonte, Minas Gerais, Brazil, 2019

\begin{tabular}{|c|c|c|}
\hline Variable & $\begin{array}{c}\text { Intensive } \\
\text { Care Unit } \\
(\mathbf{n}=30) \\
n(\%)\end{array}$ & $\begin{array}{c}\text { Hospitalization } \\
\text { Unit } \\
(\mathbf{n}=\mathbf{3 0}) \\
\mathbf{n}(\%)\end{array}$ \\
\hline \multicolumn{3}{|l|}{ Faucet model } \\
\hline Lever that can be activated using the elbow & $18(60.0)$ & $13(43.3)$ \\
\hline Pressure activation & $06(20.0)$ & $04(13.3)$ \\
\hline Activation by turning & $03(10.0)$ & $11(36.7)$ \\
\hline Sensor activation & $03(10.0)$ & $02(6.7)$ \\
\hline \multicolumn{3}{|l|}{ Sinks have soap dispensers } \\
\hline Yes & 28 (93.9) & $28(93.9)$ \\
\hline No & $02(6.7)$ & $02(6.7)$ \\
\hline \multicolumn{3}{|l|}{ Soap dispensers were in working condition } \\
\hline Yes & $27(90.0)$ & $24(80.0)$ \\
\hline No & $03(10.0)$ & $06(20.0)$ \\
\hline \multicolumn{3}{|l|}{ Type of soap dispenser } \\
\hline Pressure & $29(96.7)$ & $30(100.0)$ \\
\hline Sensor activation & $01(3.3)$ & $00(0.0)$ \\
\hline \multicolumn{3}{|l|}{ The soap dispenser was loaded } \\
\hline Yes & $27(90.0)$ & $24(80.0)$ \\
\hline No & $03(10.0)$ & $06(20.0)$ \\
\hline \multicolumn{3}{|l|}{ The sinks had alcohol dispensers } \\
\hline Yes & $20(66.7)$ & $16(53.3)$ \\
\hline No & $10(33.3)$ & $14(46.7)$ \\
\hline \multicolumn{3}{|l|}{ Alcohol dispensers were in working condition } \\
\hline Yes & $26(86.7)$ & $27(90.0)$ \\
\hline No & $04(13.3)$ & $03(10.0)$ \\
\hline \multicolumn{3}{|l|}{ Type of alcohol dispenser } \\
\hline Pressure & $30(100.0)$ & 29 (96.6) \\
\hline Sensor activation & $00(0.0)$ & $01(3.3)$ \\
\hline \multicolumn{3}{|l|}{ The alcohol dispenser was loaded } \\
\hline Yes & $24(80.0)$ & $24(80.0)$ \\
\hline No & $06(20.0)$ & $06(20.0)$ \\
\hline \multicolumn{3}{|c|}{$\begin{array}{l}\text { The alcohol and soap dispensers were next to each other in the } \\
\text { nursing station }\end{array}$} \\
\hline Yes & $16(53.3)$ & $19(63.3)$ \\
\hline No & $14(46.7)$ & $11(36.7)$ \\
\hline \multicolumn{3}{|c|}{ The alcohol and soap dispensers were next to each other in the corridor } \\
\hline No & $20(66.7)$ & $26(86.7)$ \\
\hline Yes & $10(33.3)$ & $04(13.3)$ \\
\hline \multicolumn{3}{|c|}{ The alcohol and soap dispensers were next to each other in the rooms } \\
\hline No & $19(63.3)$ & $19(63.3)$ \\
\hline Yes & $11(36.7)$ & $11(36.7)$ \\
\hline
\end{tabular}

precautions, knowledge of the five moments of hand hygiene, and identification of the fundamental principle around which RDC 42/2010 ${ }^{(15)}$ revolves.

Researches that evaluated the knowledge of health professionals with regard to bacterial resistance corroborate the findings of this study, in which this knowledge has been found to be restricted and limited ${ }^{(17-18)}$. Still in accordance with the results found, a research carried out in a Brazilian hospital found that only $8.1 \%$ of professionals correctly described the five moments of hand hygiene ${ }^{(18)}$; this was ratified by another study, carried out in Paraná, which assessed the knowledge of nursing professionals about hand hygiene, finding that $86.5 \%$ of the interviewees did not know the recommendations in their entirety ${ }^{(2,19)}$.

When professionals are unaware of elements that involve forms in which resistant bacteria can be transmitted and how to prevent this transmission, they tend to underestimate the risk and not to adopt precautions in clinical practice ${ }^{(2,18-19)}$. As a result, it is essential to continuously carry out institutional training sessions, since they lead to improvements in the knowledge of the multiprofessional team about health care processes and activities. The training sessions must promote the development of new abilities in care, integrating new professional categories ${ }^{(2,20-21)}$.

Literature about the theme is unanimous in stating that the path towards controlling the dissemination

\section{DISCUSSION}

The Ministry of Health ${ }^{(1)}$ has been requesting investigations of the difficulties showed by the professionals who plan assistance in adhering to the actions to contain bacterial resistance, requiring assessments through the situational diagnosis of the gaps that can impact in the adherence to the directives of prevention of bacterial resistance in clinical practice. From this perspective, the verification of knowledge is essential, especially when supported by institutional policies and directives of patient safety. The knowledge about preventive measures, after all, aids in molding a culture of institutional safety, standardizing care using better practices, producing a safer environment, minimizing risks, and mitigating adverse effects ${ }^{(16)}$.

This study showed that the nursing coordinators of the HUs and ICUs had insufficient knowledge about measures to contain bacterial infections, specifically with regard to standard plus contact of bacterial resistance goes through the knowledge and behavior of health professionals when confronted with recommendations of good practices ${ }^{(2,13,20)}$. The knowledge of health professionals about the mechanisms for the transmission of resistant bacteria and strategies to prevent it raise their awareness about the importance of their individual and collective practices, and about how they relate to the problem $2,13,19)$.

This means that the more the professionals understand bacterial resistance and its impacts, the greater will their perception of risk be, and, as a result, the more likely they will be to adhere to preventive measures. This is especially true for those related to standard precautions, since these are the first barrier for controlling the dissemination of resistant microorganisms $s^{(2,13,19)}$.

Still from the perspective of knowledge, studies point at the theoretical-practical insufficiency in the formation of the professionals who are working in patient care as one of the factors that contribute for the difficulties in the consolidation of measures to 
control bacteria resistance and prevent against it ${ }^{(2,21-22)}$. They also emphasize that it is necessary to rethink the teaching of this theme in graduation courses, in all fields of health formation, for changes in culture and behavior to actually take place in clinical practice ${ }^{(2,22)}$.

In this study, the low adherence to hand hygiene, the insufficient adherence to standard plus contact precautions, the absence of criteria for antibiotic prescription, the lack of supply, the sizing of personnel, the cleanliness of the environment, the flaws in the delivery of the results of cultures, and the indication of unnecessary invasive procedures were mentioned as the main difficulties to contain bacteria resistance in hospitals from Minas Gerais.

The use of standard plus contact precautions, associated to the cleaning of the environment, have been pointed out as multifaceted strategies to reduce the dissemination of resistant microorganisms in ICUs. To this end, the need to develop practices to encourage adhering to these practices in health institutions is reiterated ${ }^{(2,23)}$.

Regarding the sizing of the personnel, it is a challenge that needs to be met to contain bacterial resistance, especially considering the evidence that suggests that the small number of professionals of health care assistance, considering the large number of patients that require assistance, has a direct impact in the adherence to good practices to prevent and control infections ${ }^{(2,24)}$.

The work overload, due to undersized personnel, and the excess of patients that each member of the team needs to care for, are indicated in literature as factors that difficult the performance of care and the adherence to measures to prevent infections and disseminate resistant microorganisms ${ }^{(2,24)}$. Furthermore, studies demonstrated an association between the workload of professionals and the rate of adverse effects, showing a causal connection with the safety of the patient ${ }^{(2,24)}$.

Concerning infrastructure, studies have reiterated the importance of alcohol dispensers in the points of assistance, as recommended by the RDC 42/2010. They also indicated how important are signs to remind the worker about hand hygiene, and the availability of quality personal protection equipment in sufficient numbers, to favor the adherence to hand hygiene and standard plus contact precautions ${ }^{(2-3,22)}$. An improvement was found in the adherence to hand hygiene after alcohol dispensers were installed, coupled with reminders in the places of assistance. The same was true after the implementation of training and feedbacks ${ }^{(20)}$.

Regarding the availability of supplies for hand hygiene in the places that provide assistance, the findings of this research differ from those from other studies ${ }^{(25)}$, since, in most hospitals, the soap, alcohol, and paper towel dispensers were in working conditions, filled, and required no hand contact.

However, the distribution of these dispensers should be considered, since in more than $50 \%$ of the nursing stations the soap and alcohol dispensers were next to each other on the sinks. This placement can implicitly reinforce the idea that these procedures should be carried out sequentially, which the team should avoid ${ }^{(2-3,26)}$. This can explain what was found during observation, that the cleaning of the hands was often complemented with rubbing alcohol immediately after. The main directives from the $\mathrm{WHO}$, the $\mathrm{CDC}$, and ANVISA recommend against this procedure, since following the use of water and soap by that of alcohol contributes for the skin to become drier, in addition to wasting product ${ }^{(3,26)}$.
The rubbing of alcohol has been proved as an effective antimicrobial action when the hands are not soiled, is easy to carry out, causes less damage to the skin and saves time, but in this study, the health professionals were not aware of the effectiveness of alcohol for hand rubbing. As a result, their preference for simple hand hygiene was justified by the fact that they did not believe alcohol could be used to this end, as opposed to the recommendations ${ }^{(2,26)}$.

According to ANVISA ${ }^{(26)}$ recommendations, and to guides and directives from the $\mathrm{WHO}^{(8,18)}$, the most effective way to guarantee good hand hygiene is using alcoholic preparations, as long as the hands are not visibly soiled. This finding is justified because using alcoholic preparations for the hands has the following advantage: most microorganisms are eliminated; the product is available in the health care station; the skin tolerates it well; no special infrastructure is necessary (such as clean water, sink, soap, and towel); and, when compared to washing hands with soap and water, it takes much less time (20 to 30 seconds) $(8,18,26)$.

This research showed, clearly, how health professionals failed in their knowledge with regard to the moments of hand hygiene, as well as their lack of knowledge about the effectiveness of products and types of hand hygiene.

Furthermore, this study also calls attention to the fact that the professionals used powdered gloves. This finding is a barrier for the alcoholic rubbing of hands, since the powder, as it gets in touch with the alcoholic preparation, forms an undesirable residue in the hands, requiring the professional to use water and soap $^{(2,26)}$. Considering this limitation, and risks such as hypersensitivity and severe air passage inflammation, the Food and Drug Administration (FDA), in 2016, prohibited the use of powdered gloves in surgeries and clinical practice ${ }^{(27)}$.

However, in Brazil, at the moment of publication, health laws do not prohibit the commercialization and use of powdered gloves in health care $^{(2)}$. Both types of glove can be found for sale, and each institution is responsible for choosing which they prefer. However, the data obtained indicates that it is still necessary to invest in researchers that show the consequences of the use of each one, to provide the workers with more safety and comfort. This is relevant because, according to a study carried out in Brazil among nursing workers, institutions that are more worried about the quality of health of their workers lead to better quality in health care work ${ }^{(28)}$.

Regarding the use of fabric aprons, which are predominantly used by the professionals in the health care units of the participating hospitals, studies state that these items must be capable of preventing the dissemination of microorganisms. This means that, if they are made of fabric, they must undergo safe reprocessing mechanisms, and the maximum frequency with which these articles can be reused must be evaluated constantly, since reusing them can compromise their efficiency as a barrier to contamination $^{(2,8,29)}$. In addition, the environment and the professional may become contaminated when the reusable aprons are kept near the bed of the patients ${ }^{(2,29)}$.

Still on the impact of physical structure on the control of resistant bacteria, the $C D C$, in its Guideline for isolation precautions preventing transmission of infectious agents in healthcare settings ${ }^{(2,8)}$, highlights the effect of contact precautions. This guideline reiterates the importance of physically separating 
patients who have been colonized/infected by resistant strains from those who have not, preferably in private rooms. However, the reality of health care around the world often does not allow for such separation, making it necessary to carry out cohorts, that is, to use a strategy that separates, within the same environment, patients with similarly resistant bacteria ${ }^{(2)}$. Cohorts are accepted strategies especially in regard to endemic resistant microorganisms in institutions, working as methods to encourage the professionals to adhere to the precautions and to the measures to control the dissemination of these pathogens in the health care environment ${ }^{(8)}$. Still, the minimal distance of 1 meter between the bed of a patient and that of another ${ }^{(8)}$, which was found in most assistance units, must be respected.

The absence of an adequate infrastructure, concerning distance and the existence of physical barriers between beds, the availability of personal protection equipment, and that of supplies and quality materials for hand hygiene, are still flaws in the adherence of measures to prevent and control bacterial resistance ${ }^{(2-3,30)}$.

\section{Study limitations}

Although the observational model is seen as an important strategy in the analysis of processes and routines, the "Hawthorn Effect" may have taken place. There was an attempt not to let the professionals accompanied know that they were being observed, and all of their actions were observed as they happened, to decrease the chance they noticed they were being observed; however, the fact that they knew about the presence of the researchers may have increased their adherence to some practices. To minimize this effect, the observations were carried out in the same moment as the situational diagnosis ${ }^{(2)}$.

Furthermore, although this is a representative sample, the interviews and the observations of health care units were carried having the hospital unit as a reference, and not the number of professionals in each hospital who participated in the study. However, the results found were compatible and can be generalized, since the sample considered, of large hospitals from Minas Gerais, included more than $90 \%$ of these institutions ${ }^{(2)}$.

\section{Contributions to the field}

Studies indicate that improving the adherence to practices to control bacteria resistance requires the availability of financial resources, policies targeted at the subject, efforts and investments in training the professionals, the provision and supply of equipment, input, and physical structures that are adequate for the processes of a safe health care of quality ${ }^{(2-3,30)}$.

The support and partnership from the administration of the cities, States, and from the government is paramount to develop public actions and policies, based on the concrete reality of the institutions. Furthermore, for these policies to be effective, it is also important to carry out investigations to evaluate the knowledge about good practices to prevent and control the spread of resistant bacteria, and the difficulties that involve the adherence to these measures. This is the only way in which actions can be targeted at the gaps found, favoring their effective adoption in clinical practice.

\section{CONCLUSIONS}

This study uncovered the factors that make the control of bacterial resistance more difficult in large hospitals in Minas Gerais, such as the shortcomings in the knowledge of the professionals about preventive measures, and flaws related to the infrastructure, such as soap dispensers being positioned side-by-side in health care stations, and the absence of physical barriers between beds in health care units. Furthermore, weaknesses connected to personal protection equipment (powdered gloves and fabric aprons) were also observed.

In spite of that, this study also found factors that favor the control of bacteria resistance in the institutions: the availability of materials such as water, sink, and dispensers of soap, alcohol, and paper towels for hand hygiene. As a result, the lack of infrastructure and of supplies, that many mentioned as the cause for the non-adherence to hand hygiene, would not be a justification for non-adherence in the case of the institutions assessed here. This reiterates how important it is to adopt measures that increase knowledge and to monitor actions targeted at controlling bacterial resistance in the clinical practice.

\section{REFERENCES}

1. Ministério da Saúde (BR). Agência Nacional de Vigilância Sanitária. Medidas de Prevenção de Infecção Relacionada à Assistência à Saúde [Internet]. Brasília: ANVISA; 2017 [cited 2019 May 23]. Available from: https://www20.anvisa.gov.br/segurancadopaciente/index.php/ publicacoes/item/caderno-5

2. Mello MS. Ações para prevenção e controle da resistência bacteriana em hospitais de grande porte de Minas Gerais[Dissertação] [Internet]. 2019 [cited 2019 May 15]. Available from: https://repositorio.ufmg.br/handle/1843/31014

3. Oliveira AC, Paula AO, lquiapaza R, Gama CS. Profile of microorganisms associated with colonization and infection in intensive therapy. Rev Epidemiol Control Infec [Internet]. 2017 [cited 2019 Sep 12];7(2). Available from: https://online.unisc.br/seer/index.php/epidemiologia/article/view/8302

4. European Centre for Disease Prevention and Control. Surveillance of antimicrobial resistance in Europe [Internet]. 2018 [cited 2019 May 15]. Available from: https://www.ecdc.europa.eu/en/publications-data/surveillance-antimicrobial-resistance-europe-2018

5. Matos ECO, Matos HJ, Conceição ML, Rodrigues YC, Carneiro ICRS, Lima KVB. Clinical and microbiological features of infections caused by Pseudomonas aeruginosa in patients hospitalized in intensive care units. Rev Soc Bras Med Trop [Internet]. 2016 [cited 2019 Sep 12];49(3):305-11. Available from: https://www.ncbi.nlm.nih.gov/pubmed/27384827

6. Hoang S, Georget A, Asselineau J, Venier AG, Leroyer C, Rogues AM, et al. Risk factors for colonization and infection by Pseudomonas aeruginosa in patients hospitalized in intensive care units in France. PLoS One. 2018;13(3): e0193300. https://doi.org/10.1371/journal.pone.0193300. 
7. Ministério da Saúde (BR). Agência Nacional de Vigilância Sanitária. Uso racional de antimicrobiano e a resistência microbiana. Modelo3: Resistência Microbiana - Mecanismos e Impacto Clínico [Internet]. Brasília: ANVISA; 2007 [cited 2019 May 17]. Available from: https://www. anvisa.gov.br/servicosaude/controle/rede_rm/cursos/rm_controle/opas_web/modulo3/mec_enzimatico.htm

8. Centres for Disease Control and Prevention. Guideline for isolation precautions: preventing transmission of infectious agents in healthcare settings [Internet]. 2007 [cited 2019 May 17]. Available from: https://www.cdc.gov/niosh/docket/archive/pdfs/NIOSH-219/0219-010107siegel.pdf

9. Jinadatha C, Villamaria FC, Coppin JD, Dale CR, Williams MD, Whitworth R, et al. Interaction of healthcare worker hands and portable medical equipment: a sequence analysis to show potential transmission opportunities. BMC Infect Dis. 2017;17(1):800. https://doi.org/10.1186/ s12879-017-2895-6

10. De la Rosa-Zamboni D, Ochoa SA, Laris-González A, Cruz-Córdova A, Escalona-Venegas G, Pérez-Avendaño G, et al. Everybody hands-on to avoid ESKAPE: effect of sustained hand hygiene compliance on healthcare-associated infections and multidrug resistance in a paediatric hospital. J Med Microbiol. 2018;67(12):1761-71. https://doi.org/10.1099/jmm.0.000863

11. Lacerda M, Souza S, Soares D, Silveira B, Lopes J. Standard precautions and precautions based on transmission of diseases: literature review. Epidemiol Control Infec [Internet]. 2014 [cited 2019 Sep. 23];4(4):254-9. Available from: https://online.unisc.br/seer/index.php/ epidemiologia/article/view/4952

12. World Health Organization (WHO). Global Action Plan on Antimicrobial Resistance [Internet]. Geneva: WHO; 2015 [cited 2019 Sep. 23 ]. Available from: https://www.who.int/antimicrobial-resistance/global-action-plan/en/

13. Oliveira AC, Gonzaga C, Costa R, Damaceno QS, Garbaccio JL. Desafios e perspectivas para a contenção da resistência bacteriana na óptica dos profissionais de saúde. Rev Eletron Enferm [Internet]. 2013 [cited 2019 Sep. 23];15(3):747-755. Available from: https://revistas.ufg.br/fen/ article/view/19821

14. Ministério da Saúde (BR). Portaria n².224/GM - Sistema de classificação hospitalar do Sistema Único de Saúde, de 5 de dezembro de 2002 [Internet]. Brasília (DF): Ministério da Saúde; 2002 [cited 2019 Sep 23]. Available from: http://www.sbccv.org.br/medica2-old/downloads/ Portaria\%20n\%C2\%BA\%202.224-GM\%20Em\%205\%20de\%20dezembro\%20de\%202002.pdf

15. Ministério da Saúde (BR). Agência Nacional de Vigilância Sanitária. Resolução - RDC 42 de 25 de outubro de 2010 - Dispõe sobre a obrigatoriedade de disponibilização de preparação alcoólica para fricção antisséptica das mãos, pelos serviços de saúde do País, e dá outras providências [Internet]. Brasília: ANVISA; 2010 [cited 2019 Sep 23]. Available from: https://bvsms.saude.gov.br/bvs/saudelegis/anvisa/2010/ res0042_25_10_2010.html

16. Drekonja DM, Grigoryan L, Lichtenberger P, Graber CJ, Patel PK, Van JN, et al. Teamwork and safety climate affect antimicrobial stewardship for asymptomatic bacteriuria. Infect Control Hosp Epidemiol [Internet]. 2019 [cited 2019 Sep 23];40(9):963-967. https://doi.org/10.1017/ ice.2019.176

17. Baloh J, Thom KA, Perencevich E, Rock C, Robinson G, Ward M, et al. Hand hygiene before donning nonsterile gloves: healthcare workers' beliefs and practices. Am J Infect Control. 2019;47(5):492-497. https://doi.org/10.1016/j.ajic.2018.11.015

18. Oliveira AC, Pinto SA. Participação do paciente na higienização das mãos entre profissionais de saúde. Rev Bras Enferm. 2018;71(2):259-64. https://doi.org/10.1590/0034-7167-2016-0124

19. Derhun FM, SouzaVS, Costa MAR, Inoue KC, Matsuda LM. Conhecimento de profissionais de enfermagem sobre higienização das mãos. Cogitare Enferm. 2016;21(3):1-8. https://doi.org/10.5380/ce.v21i3.45588

20. Saharman YR, Aoulad FD, El-Atmani S, Sedono R, Aditianingsih D, Karuniawati A, et al. A multifaceted hand hygiene improvement program on the intensive care units of the National Referral Hospital of Indonesia in Jakarta. Antimicrob Resist Infect Control. 2019;8(1). https://doi. org/10.1186/s13756-019-0540-4

21. Hinkin J, Cutter J. How do university education and clinical experience influence pre-registration nursing student's infection control practice? a descriptive, cross sectional survey. Nurse Educ Today. 2014;34(2):196-201. https://doi.org/10.1016/j.nedt.2013.09.005

22. Massaroli A, Martini JG, Moya JLM, Bitencourt JVOV, Reibnitz KS, Bernardi MC. Teaching of infection control in undergraduate courses in health sciences: opinion of experts. Rev Bras Enferm. 2018;71(4):1626-34. https://doi.org/10.1590/0034-7167-2017-0928

23. Hong J, Jang OJ, Bak MH, Baek EH, Park KH, Hong SI, et al. Management of carbapenem-resistant Acinetobacter Baumannii epidemic in an intensive care unit using multifaceted intervention strategy. Korean J Intern Med. 2018;33(5):1000-7. https://doi.org/10.3904/kjim.2016.323

24. Lorenzini E, Deckmann LR, Costa TC, Silva EF. Dimensionamento de pessoal de enfermagem: revisão integrativa. Cienc Cuid Saúde. 2014;13(1):166-71. https://doi.org/10.4025/cienccuidsaude.v13i1.15959

25. Prado MF, Hartmann TPS, Teixeira FLA. Acessibilidade da estrutura física hospitalar para a prática da higienização das mãos. Esc Anna Nery [Internet]. 2013 [cited 2019 Sep 23];17(2):220-6. Available from: http://www.scielo.br/pdf/ean/v17n2/v17n2a03.pdf

26. Ministério da Saúde (BR). Agência de Vigilância Sanitária. Nota técnica n. 01/2018 GVIMS/GGTES/ANVISA: orientações gerais para a higiene das mãos em serviços de saúde [Internet]. Brasília: ANVISA; 2018 [cited 2019 Sep 23]. Available from: https://www20.anvisa.gov.br/segurancadopaciente/index. php/alertas/item/nota-tecnica-n-01-2018-gvims-ggtes-anvisa-orientacoes-gerais-para-higiene-das-maos-em-servicos-de-saude

27. Food and Drug Administration. Banned devices; powdered surgeon's gloves, powdered patient examination gloves, and absorbable powder for lubricating a surgeon's glove [Internet]. 2016 [cited 2019 Sep 23]. Available from: https://www.federalregister.gov/ documents/2016/12/19/2016-30382/banned-devices-powdered-surgeons-gloves-powdered-patient-examination-gloves-and-absorbable-powder 
28. Carvalho DC, Rocha JC, Gimenes MCA, Santos EC, Valim MD. Work-related psychosocial and mechanical risk factors for low back pain: a work incident with biological material in the nursing team of a hospital in Mid-Western Brazil. Esc Anna Nery [Internet]. 2018 [cited 2020 Jan 04];22:1-8. Available from: http://www.scielo.br/pdf/ean/v22n1/pt_1414-8145-ean-2177-9465-EAN-2017-0140.pdf

29. Pissinati PSC, Haddad MCL, Rossaneis MA, Gil RB, Belei RA. Custos de aventais de tecido reutilizáveis e de descartáveis em hospital universitário público. Rev Esc Enferm USP. 2014;48(5):915-921. https://doi.org/10.1590/S0080-623420140000500019

30. Ministério da Saúde (BR). Agência Nacional de Vigilância Sanitária. Nota Técnica GVIMS/GGTES n. 05/2017 - revisada. Orientações para a notificação nacional das Infecções Relacionadas à Assistência à Saúde (IRAS), Resistência Microbiana (RM) e monitoramento do consumo de antimicrobianos [Internet]. Brasília: ANVISA, 2018 [cited 2019 Sep 23]. Available from: http://www.saude.pi.gov.br/uploads/divisa_ document/file/386/Nota_t\%C3\%A9cnica_n\%C2\%BA_01-2019_GVIMS-GGTES-ANVISA.pdf 